\title{
Mechanism of crop growth promotion and responses to various environmental stresses with different plant extracts
}

\author{
Se Ji Jang, Yong In Kuk \\ Department of Oriental Medicine Resources, Sunchon National University, Suncheon, Republic of Korea
}

\begin{abstract}
Our objective in this study was to determine to what degree macro and micro nutrients in water extracts, ethanol extracts and whole plant applications of Chinese chive (CC), soybean leaf (SL) and soybean stem (SS) promoted crop growth and if growth promotion was related to physiological elements such as photosynthetic efficiency. The studies we conducted in Suncheon, South Korea in 2017 also sought to confirm crop responses to abiotic and biotic stresses after treatment with $\mathrm{CC}, \mathrm{SL}$ and SS extracts. We found that most nutrient levels in CC, SL and SS water extracts were higher than in ethanol extracts. Thus, growth promotion effectiveness may be related to plant extraction method, but not to the plants themselves or to physiological elements. Boiled water extracts of SL at 5\% suppressed some fungi by $92 \%$ (Bortytis cinereal) and 57\% (Colletotrichum coccodes), however several others were not effectively suppressed. Compared to the control, rice plant injuries induced by $50 \mathrm{mM} \mathrm{NaCl}$ were reduced by 20 $39 \%, 41-46 \%$, and $40-46 \%$ in response to CC, SL and SS extract treatments at $0.5,1$, and $3 \%$, respectively. Shoot fresh weight of rice subjected to $50 \mathrm{mM}$ also increased by $38 \%, 15-52 \%$, and $40-$ $59 \%$ in response to treatments of CC, SL or SS extracts at $0.5,1$, and $3 \%$, respectively. Rice injuries under drought conditions were reduced $20-26 \%$ in response to treatment with CC, SL and SS
\end{abstract}

Correspondence: Yong In Kuk, Department of Oriental Medicine Resources, Sunchon National University, Suncheon 57922, Republic of Korea.

E-mail: yikuk@sunchon.ac.kr

Key words: Environmental stress; growth promotion; plant extract; rice.

Acknowledgements: this work was carried out with the support of Cooperative Research Program for Agriculture Science \& Technology Development (Project No. PJ 008423) Rural Development Administration, Republic of Korea.

Received for publication: 30 May 2019.

Revision received: 7 October 2019.

Accepted for publication: 5 November 2019.

(C) Copyright: the Author(s), 2019

Licensee PAGEPress, Italy

Italian Journal of Agronomy 2019; 14:1488

doi:10.4081/ija.2019.1488

This article is distributed under the terms of the Creative Commons Attribution Noncommercial License (by-nc 4.0) which permits any noncommercial use, distribution, and reproduction in any medium, provided the original author(s) and source are credited. extracts at 1, 3, and 5\% when compared with control plants. Furthermore, the shoot fresh weight of rice under drought conditions was 3.6, 2.0, and 3.2 times greater when treated with CC, SL and SS extracts at 5\%, respectively. Thus, the CC, SL and SS extracts used in this study mitigate salt and drought stresses and fungicidal effects, as well as promoting crop growth and could therefore contribute substantially to sustainable crop production.

\section{Introduction}

The world's population is increasing at an alarming rate and is expected to reach approximately ten billion by the end of 2050 . However, crop productivity is decreasing in response to climate change and various abiotic stresses (FAO, 2017). Minimising these losses is a major challenge that all nations must cope with in order to ensure that increasing food requirements are met. For this reason, we have sought to better understand alternative means of increasing crop productivity not only through fertilisers, but also growth-promoting plant extracts (Jardin, 2015; Jang, 2017; Jang and Kuk, 2019).

Exogenous application of plant growth regulators, nutrients, and organic and inorganic chemicals have been used to promote plant growth and develop abiotic and biotic stress tolerance that results in greater crop yields (Abd El-Rahman and Mohamed, 2014). However, the continuous use of synthetic chemicals is usually not environmentally friendly. Thus, the search for safe and effective natural products, mainly as growth stimulators, is now focused on edible plants, especially vegetative plants (Nakatani, 1997). Among naturally occurring plant growth enhancers, Moringa oleifera Lam. has received enormous attention because it contains cytokinin-like zeatin, antioxidants such as ascorbic acid, flavonoids, phenolics, carotenoids, amino acids, and macro and micro nutrients in its leaves (Foidl et al., 2001; Ndhlala et al., 2014). Treatment with Moringa oleifera leaf extract has been shown to promote seed germination as well as growth and productivity of many crops under normal (Nouman et al., 2012) and stressful conditions (Yasmeen et al., 2012, 2013).

The adverse effects of abiotic stress on plant health and production is a hindrance which demands immediate attention and suitable solutions. Common abiotic stresses such as drought, salinity, and extreme temperatures can reduce the yield of major crops (Wang et al., 2003a, 2003b) and limit agricultural production worldwide. Salinity and drought are becoming so widespread that an estimated $50 \%$ of all arable lands might be salinized by 2050 (Flowers and Yeo, 1995). Many abiotic factors manifest themselves as osmotic stress and cause secondary effects such as oxidative stress, leading to accumulation of reactive oxygen species (ROS) such as the superoxide anion $\left(\mathrm{O}_{2}^{-}\right)$and hydrogen peroxide $\left(\mathrm{H}_{2} \mathrm{O}_{2}\right)$ (Mittler, 2002). These compounds are known to damage DNA, lipids, carbohydrates, and proteins, as well as cause aberrant cell signalling (Arora et al., 2002). With the apparent 
damage caused to crops by abiotic stress in mind, our study has explored how applications of plant extracts might be used to reduce plant stress while also being environmentally-friendly.

The extracts of soybean (Glycine max (L.) Merr.) and Chinese chive (Allium tuberosum Rottler) leaves (CC) contain antioxidant compounds such as flavonoids, phenolic acids and minerals and may therefore be effective in increasing crop yields by helping the crops better cope with environmental stress (Stutte and Park, 1973; Porter et al., 1985; Moon et al., 2003; Jang, 2017). However, no studies conducted to date have established if CC, soybean leaf(SL) and soybean stem (SS) extracts, or their chemical components, could protect plants against abiotic stresses. Thus, the purpose of this study was threefold. First, this study was conducted to determine if increases in crop growth induced by $\mathrm{CC}$, SL and SS extracts are related to macro and micro elements in the selected plants themselves and their water and ethanol extracts. The second purpose was to investigate whether the increase in crop growth in response to plant extracts was also related to photosynthetic efficiency (quantum yield), chlorophyll and carotenoid contents. Finally, we sought to better understand how crops respond to abiotic and biotic stresses after treatment with selected plant extracts.

\section{Materials and methods}

\section{Experimental design}

Experiments conducted in order to determine the levels of macro and micronutrients present in CC, SL, and SS analysed both whole plant and extracts. Experiments had a completely randomised design and were repeated once. Significant differences were determined using Analysis of Variance (ANOVA). Analyses were performed using Statistical Analysis Systems (SAS, 2000) software. In the case of significant difference, means were separated by Duncan's Multiple Range Test at $\mathrm{P} \leq 0.05$.

\section{Plant materials and treatments}

SL and SS, and rice seeds (cv. Dongjinbyeo) were provided from Jeollanamdo Agricultural Research and Extension Service after harvest in 2016. Dried powder of CC leaves made from leaves harvested 80 days after seeding in 2016 and cucumber (Cucumis sativus L.) seeds were purchased from Chonnam Hanyaknonghyup Corporation (Hwasun, South Korea) and Korean Seed Cooperation, respectively. The SL and SS were dried in a drying oven at $45^{\circ} \mathrm{C}$ for 3 days and were ground to pass a 2-mm screen using a coffee grinder (Proctor Silex E160B, Southern Pines, NC). Cultural management practices were carried out in accordance with the standard crop cultivation method of the Rural Development Administration of Korea (RDA, 1998).

In our water extract, $50 \mathrm{~g}$ ground $\mathrm{SL}, \mathrm{SS}$, and $\mathrm{CC}$ were mixed with $1000 \mathrm{~mL}$ distilled water for $24 \mathrm{~h}$. In our ethanol extract, we followed the same process but instead used $1000 \mathrm{~mL}$ ethanol for 24 h. In our boiled extract, the $50 \mathrm{~g}$ ground SL, SS, and CC were mixed with $1000 \mathrm{~mL}$ distilled water and then boiled at $100^{\circ} \mathrm{C}$ for $30 \mathrm{~min}$ (Jang and Kuk, 2019). For studies of pathogen suppression, we used water, boiled water and ethanol extracts.

\section{Mineral nutrients in selected plants and their extracts}

$0.5 \mathrm{~g}$ of CC, SL and SS ground materials were used to analyse nutrient concentrations based on the micro-Kjeldahl procedure (RDA, 2000). Additionally, water and ethanol extracts of CC, SL and SS were used to analyse nutrient concentrations based on the
micro-Kjeldahl procedure (RDA, 2000). The samples were placed in tubes containing an acid-digestion mixture $\left(18 \mathrm{~mL} \mathrm{H}_{2} \mathrm{O}_{2}, 1.0 \mathrm{~L}\right.$ $\mathrm{H}_{2} \mathrm{SO}_{4}$, and $0.6 \mathrm{~g}$ salicylic acid), which were then heated on a block digester at $280^{\circ} \mathrm{C}$, allowed to cool for $15 \mathrm{~min}$, and then filled with de-ionized water to $50 \mathrm{~mL}$. The digested solution was analysed using an automated $\mathrm{N}$ analyser (Buchi Co., Flawil, Switzerland) to determine the total $\mathrm{N}$ concentration with a UV-Visible spectrophotometer (UV-1601; Shimadzu Co., Kyoto, Japan) at $470 \mathrm{~nm}$ for concentration of $\mathrm{P}$, and an inductively coupled plasma atomic emission spectroscopy for other minerals such as $\mathrm{K}, \mathrm{Ca}$, and $\mathrm{Mg}$. Although CC, SL and SS were the main focus of our study, we also wanted to study similar leguminous crops to determine if they too were effective growth regulators. For additional study, we analysed nutrient concentrations in cowpea leaves and stems, mung bean leaves and stems, and red bean leaves. The analysis procedures for the nutrient concentrations in $\mathrm{CC}, \mathrm{SL}$ and $\mathrm{SS}$ were the same as those described above.

\section{Photosynthetic efficacy, chlorophyll and carotenoid contents}

Chlorophyll $a$ fluorescence of photosystem II (PSII), i.e., the quantum yield $\left(\mathrm{F}_{\mathrm{v}}-\mathrm{F}_{\mathrm{m}}\right)$, chlorophyll and carotenoid contents of lettuce were measured at $1,3,5$, and 7 days after treatments of plant extracts. The water extracts used were at concentrations of $1 \%, 3 \%$ and $5 \%$. Each plant at the 3 -leaf stage received $5 \mathrm{~mL}$ of extracts applied using a hand sprayer. In vivo chlorophyll fluorescence of PSII was determined by a portable pulse modulation fluorometer (PAM 2500, Walz, Effeltrich, Germany). Prior to measurements, fronds were dark adapted for $15 \mathrm{~min}$ to open all antennae pigments. Chlorophyll was assayed according to the procedure of Hiscox and Israelstam (1979). The leaves of seedlings $(0.5 \mathrm{~g})$ from each treatment were soaked for $48 \mathrm{~h}$ in $10 \mathrm{~mL}$ of dimethyl sulfoxide in darkness and at room temperature. Total chlorophyll content in the extracts was determined spectrophotometrically. For carotenoid analysis, leaves of seedlings $(0.5 \mathrm{~g})$ were ground in a solution of $100 \%$ methanol. The extracts were centrifuged at $10,000 \times \mathrm{g}$ for $3 \mathrm{~min}$ and absorbance of the supernatants was recorded at 665,652 , and $470 \mathrm{~nm}$ spectrophotometrically. The contents of chlorophylls and carotenoids were calculated using the following equations:

Chlorophyll a $\left(\mathrm{C}_{\mathrm{a}}\right)=16.72 \mathrm{~A}_{665.2}-9.16 \mathrm{~A}_{652.4}$ Chlorophyll b $\left(\mathrm{C}_{\mathrm{b}}\right)=34.09 \mathrm{~A}_{652.4}-15.28 \mathrm{~A}_{665.2}$ Total chlorophylls $\left(\mathrm{C}_{\mathrm{a}+\mathrm{b}}\right)=1.44 \mathrm{~A}_{665.2}+24.93 \mathrm{~A}_{652.4}$ Total carotenoids $\left(\mathrm{C}_{\mathrm{x}+\mathrm{c}}\right)=1000 \mathrm{~A}_{470.0}-1.63 \mathrm{C}_{\mathrm{a}}-104.96 \mathrm{C}_{\mathrm{b}}$

\section{1}

\section{Responses to biotic stresses by selected plant extract treatments}

To determine whether or not our selected growth promoting plant extracts were also effective in reducing damage cause by fungi, we conducted experiments using five fungal pathogens: Pyricularia oryzae, Bortytis cinerea, Rhizoctonia solani, Phytophthora capsici, and Colletotrichum coccodes. These particular fungal pathogens were selected because they are both common and destructive in South Korean organic agriculture. We used water, boiled water or ethanol extracts at a $5 \%$ concentration $(\mathrm{w} / \mathrm{v})$. $10 \mathrm{~mL}$ of the plant extracts were added to potato dextrose agar (PDA) media in Petri dishes $(90 \mathrm{~mm})$. After solidification, mycelia plugs $(10 \mathrm{~mm}$ diameter) of the aforementioned pathogens were placed in the centre of the Petri dishes and incubated at $26^{\circ} \mathrm{C}$ in 
darkness (Jang and Kuk, 2018). Three-day-old cultures of the test fungus grown on PDA medium were used for bioassays. Mycelial radial growth of the test fungus was measured at 3 days after treatment. The suppression activity was calculated using colony diameter growth of treated plates compared to control plates (PDA medium without extract). The extracts were also sprayed $(5 \mathrm{~mL}$ per plant) with a hand sprayer at the 3 leaf-stage of cucumber (cv. Hodongchungjang) plants which had been inoculated with powdery mildew (Sphaerotheca fuliginea) fungus in order to determine controlling value of powdery mildew. The concentrations of plant extracts treated were 1,3 , and 5\%, and the controlling value evaluated at 7 days after treatment. The calculation of controlling value is as follows:

Controlling value $(\%)=(1-$ symptom area in treated plot/symptom area in untreated plot) $\times 100$

Thirty-two-spotted spider mite adult females were inoculated on a kidney bean leaf disc (diameter $4 \mathrm{~cm}$ ) and then sprayed with plant extracts at $3 \%, 5 \%$, and $10 \%$ concentrations with a hand sprayer. Acaricidal activity was investigated at 1,3, and 5 days after treatment.

\section{Responses to various environmental stresses by selected plant extract treatments}

To determine whether crop growth promotion in selected plant extracts correlates with other environmental stresses, cucumber and rice plants were tested. The selected plant water extracts were sprayed at $0.5,1,3$, and $5 \%$ in chilling temperature and drought experiments. Cucumber plants at 4-leaf stage (one plant per treatment) were exposed to chilling temperature at $10 \square$, for $12,24,48$, and $72 \mathrm{~h}$ in a growth chamber with a relative humidity of $60 \%, 150$ $\mu \mathrm{mol} \mathrm{m} \mathrm{m}^{-2} \mathrm{~s}^{-1}$ photosynthetically active radiation, and a $14 / 10 \mathrm{~h}$ day/night period. For treatments applied under drought conditions, rice plants at 2-leaf stage (three plants per treatment) were mim- icked by equilibrating the water potential until the treatment, after which no water was applied throughout the experiment. One group of plants was maintained under optimal irrigation (control) and the other group was subjected to drought by withholding water for 168 $\mathrm{h}$ in the growth chamber. After this, these plants given water for $120 \mathrm{~h}$ in order to recover.

For $\mathrm{NaCl}$ treatment, rice plants at 2-leaf stage were treated at 50 and $100 \mathrm{mM} \mathrm{NaCl}$ alone or plant extract at $0.5,1$ or $3 \%+50$ and $100 \mathrm{mM} \mathrm{NaCl}$ combinations for $168 \mathrm{~h}$ in the growth chamber. Leaf damage in the treated plants was evaluated at $12,24,48$, and $72 \mathrm{~h}$ after cold treatment and 24,72,120, and $168 \mathrm{~h}$ after drought treatment and $\mathrm{NaCl}$ stresses by visually comparing the level of damage. Plant height and shoot fresh weight were also measured at $168 \mathrm{~h}$ after cold, drought, and $\mathrm{NaCl}$ treatments.

\section{Results and discussion}

\section{Mineral nutrients in selected plants and their extracts}

To investigate whether the increase in crop growth by plant extracts was related to mineral nutrients, we determined the macro and micro elements in both the selected plants themselves and their extracts (Table 1). The K, P, T-N, Na, Cr, and Mo contents in CC were higher than those of SL and SS. Additionally, $\mathrm{Ca}, \mathrm{Mg}, \mathrm{B}, \mathrm{Al}$, $\mathrm{Ti}, \mathrm{Mn}, \mathrm{Fe}, \mathrm{Ni}$, and $\mathrm{Zn}$ contents in SL were higher than those of CC and SS. Furthermore, most mineral nutrients in SL were higher than those in SS. Overall, the order of mineral nutrient levels was $\mathrm{SL}>\mathrm{CC}>\mathrm{SS}$.

Although the mineral nutrient levels in SL were the greatest, SL did not produce the highest levels of growth promotion (Jang and Kuk, 2019). Thus, mineral nutrient levels in the plants themselves may not be related to mechanisms of growth promotion.

We also determined the mineral nutrient levels in other legumi-

Table 1. Chemical compositions in selected plants.

\begin{tabular}{|c|c|c|c|c|}
\hline Element & & Chinese chive & Soybean leaf & Soybean stem \\
\hline Ex. Cat $(\mathrm{cmol}+/ \mathrm{kg})$ & $\begin{array}{l}\mathrm{K} \\
\mathrm{Ca} \\
\mathrm{Mg}\end{array}$ & $\begin{array}{l}3.90^{\mathrm{a}} \\
1.19^{\mathrm{b}} \\
0.38^{\mathrm{b}}\end{array}$ & $\begin{array}{l}1.20^{\mathrm{b}} \\
3.96^{\mathrm{a}} \\
0.71^{\mathrm{a}}\end{array}$ & $\begin{array}{l}0.03^{c} \\
0.85^{c} \\
0.29^{c}\end{array}$ \\
\hline Av. P2O5 (mg/kg) & & $0.25^{\mathrm{a}}$ & $0.12^{\mathrm{b}}$ & $0.03^{c}$ \\
\hline T-N (\%) & & $2.72^{\mathrm{a}}$ & $1.53^{\mathrm{b}}$ & $0.44^{c}$ \\
\hline $\mathrm{Na}_{2} \mathrm{O}(\mathrm{ppm})$ & & $0.18^{a}$ & $0.01^{\mathrm{b}}$ & $0.06^{\mathrm{b}}$ \\
\hline B (ppm) & & $11.3^{b}$ & $38.71^{\mathrm{a}}$ & $10.92^{b}$ \\
\hline $\mathrm{Al}(\mathrm{ppm})$ & & $131.55^{\mathrm{b}}$ & $434.54^{\mathrm{a}}$ & $34.63^{c}$ \\
\hline $\mathrm{Ti}(\mathrm{ppm})$ & & $9.95^{\mathrm{b}}$ & $29.94^{\mathrm{a}}$ & $2.23^{c}$ \\
\hline $\mathrm{Cr}$ (ppm) & & $3.32^{\mathrm{a}}$ & $1.84^{\mathrm{b}}$ & $0.89^{c}$ \\
\hline Mn (ppm) & & $36.68^{b}$ & $175.15^{\mathrm{a}}$ & $9.32^{\mathrm{c}}$ \\
\hline Fe (ppm) & & $138.46^{\mathrm{b}}$ & $324.36^{\mathrm{a}}$ & $42.33^{\mathrm{c}}$ \\
\hline $\mathrm{Ni}(\mathrm{ppm})$ & & $0.23^{c}$ & $0.81^{\mathrm{a}}$ & $0.65^{b}$ \\
\hline $\mathrm{Cu}(\mathrm{ppm})$ & & $3.11^{\mathrm{a}}$ & $3.2^{\mathrm{a}}$ & $3.08^{a}$ \\
\hline Zn (ppm) & & $34.4^{\mathrm{b}}$ & $49.56^{\mathrm{a}}$ & $6.43^{c}$ \\
\hline As (ppm) & & $3.06^{\mathrm{a}}$ & $3.22^{\mathrm{a}}$ & $2.91^{\mathrm{a}}$ \\
\hline Mo (ppm) & & $3.31^{\mathrm{a}}$ & $1.94^{\mathrm{b}}$ & $0.5^{\mathrm{c}}$ \\
\hline Total & & 383.99 & 1070.8 & 115.59 \\
\hline
\end{tabular}

a-c Means within a row followed by the same letters are not significantly different at 5\% level according to Duncan's Multiple Range Test. 
nous crops (Table 2). The contents of $\mathrm{Ca}, \mathrm{Mg}, \mathrm{P}, \mathrm{N}, \mathrm{B}, \mathrm{Al}, \mathrm{Ti}, \mathrm{Mn}$, $\mathrm{Fe}, \mathrm{Zn}$ and $\mathrm{As}$ in cowpea leaves were higher than in cowpea stems. Moreover, the contents of $\mathrm{Ca}, \mathrm{P}$, and $\mathrm{Fe}$ in mung bean leaves were higher than those of mung bean stems. Additionally, the Al, Ti, Fe, $\mathrm{Ni}$, and $\mathrm{Zn}$ contents in red bean leaves were higher than in cowpea leaves and stems, as well as in mung bean leaves and stems. Although the mineral contents in cowpea leaves and mung bean leaves were higher than those in each of their stems, the levels of growth promotion were similar between leaves and stems of each crop. As shown in a previous study (Jang and Kuk, 2019), water extracts of CC, SL, and SS were more effective in growth promotion in lettuce plants than ethanol extracts. Thus, we measured the levels of mineral nutrients in both water and ethanol extracts of $\mathrm{CC}, \mathrm{SL}$, and SS to confirm the mechanisms of growth promotion (Table 3). The levels of macro elements such as $\mathrm{Ca}, \mathrm{Mg}, \mathrm{P}$, and $\mathrm{T}-$ $\mathrm{N}$ in water extract of $\mathrm{CC}$ leaves were higher than those of their ethanol extracts. Water extracts of CC leaves also had much greater levels of micro elements such as $\mathrm{B}, \mathrm{Mn}, \mathrm{Fe}, \mathrm{Cu}$, and $\mathrm{Mo}$ than ethanol extracts. Specifically, Ca, P, and B contents in water extracts of CC leaves were seven times higher than those of their ethanol extracts. The levels of most macro and micro elements, such as $\mathrm{Ca}, \mathrm{Mg}, \mathrm{Fe}$, and $\mathrm{Mo}$ in water extract of SL were higher than those of their ethanol extracts. Furthermore, $\mathrm{Ca}, \mathrm{Mn}$, and $\mathrm{B}$ contents were 14 times higher than those of their ethanol extracts. Additionally, the $\mathrm{Ca}, \mathrm{P}, \mathrm{Ni}$, and $\mathrm{Cu}$ contents in $\mathrm{SL}$ were higher than those of ethanol extracts. Overall, most macro and micro element contents of water extracts of CC, SL, and SS were much higher than those of ethanol extracts. In another study, the growth promoting effects of two seaweed suspensions (brown algae Ascophyllum nodosum and lamina of Laminaria hyperborean) on lettuce were solely due to a mineral component, K (Möller and Smith, 1998). Furthermore, seaweed components such as macro- and microelement nutrients, amino acids, vitamins, cytokinins, auxins, and abscisic acid (ABA)-like growth substances affect cellular metabolism in treated plants leading to enhanced growth and crop yield (Khan et al., 2009). Thus, the growth promotion of lettuce plants by plant extracts may be related to the higher mineral nutrient contents in the extracts.

\section{Photosynthetic efficacy, chlorophyll and carotenoid contents in lettuce plants treated with plant extracts}

There were no significant differences in photosynthetic efficiency, chlorophyll or carotenoid contents in lettuce plants treated with CC, SL and SS water extracts and the untreated control (Table 4). These findings imply that the increased growth found in extract-treated lettuce plants was not related to the photosynthetic efficiency (quantum yield) or the chlorophyll and carotenoid contents. In another study, spraying common bean (Phaseolus vulgaris) plants with Moringa oleifera leaf extract caused a significant increase in photosynthetic pigments relative to stressed plants (Latif and Mohamed, 2016). Moreover, the leaves of Moringa oleifera have several macro elements, including Mg (Yameogo et al., 2011), a constituent of chlorophyll, would account for the increase in the amount of chlorophyll a and chlorophyll b in common bean plants. Thus, the promotional effects of plant extracts in lettuce plants may be related to the higher mineral nutrient contents in the plant extracts used and the induction of hormone-like substances. However, we did not detect hormone levels in the plant extracts in this study.

\section{Responses of plants treated with selected plant extract treatments to biotic stresses}

To determine the suppression rates of five crop pathogens, the selected plant extracts that had growth promotion effects toward lettuce plants were investigated. Generally, suppression rates of Pyricularia oryzae, Rhizoctonia solani, and Phytophthora capsici were below 33\% following treatment with selected SL and SS extracts at $5 \%$, regardless of extraction methods (Table 5). However, Rhizoctonia solani was suppressed by $49 \%$ in response to SS water extract at $5 \%$ when compared with the control.

Table 2. Chemical compositions in other leguminous crops.

\begin{tabular}{|c|c|c|c|c|c|c|}
\hline Element & & Cowpea leaf & Cowpea stem & Mung bean leaf & Mung bean stem & Red bean leaf \\
\hline Ex. Cat (cmol+/kg) & $\begin{array}{l}\mathrm{K} \\
\mathrm{Ca} \\
\mathrm{Mg}\end{array}$ & $\begin{array}{l}1.50^{\mathrm{c}} \\
1.31^{\mathrm{b}} \\
1.10^{\mathrm{a}}\end{array}$ & $\begin{array}{l}2.04^{b} \\
0.50^{c} \\
0.49^{c}\end{array}$ & $\begin{array}{l}2.00^{\mathrm{b}} \\
1.85^{\mathrm{a}} \\
0.58^{\mathrm{c}}\end{array}$ & $\begin{array}{l}3.42^{\mathrm{a}} \\
0.64^{\mathrm{c}} \\
0.52^{\mathrm{c}}\end{array}$ & $\begin{array}{l}1.24^{\mathrm{d}} \\
1.72^{\mathrm{a}} \\
0.68^{\mathrm{b}}\end{array}$ \\
\hline Av. $\mathrm{P}_{2} \mathrm{O}_{5}(\mathrm{mg} / \mathrm{kg})$ & & $0.04^{\mathrm{a}}$ & $0.04^{\mathrm{a}}$ & $0.04^{\mathrm{a}}$ & $0.03^{b}$ & $0.04^{\mathrm{a}}$ \\
\hline $\mathrm{T}-\mathrm{N}(\%)$ & & $0.019^{c}$ & $0.009^{d}$ & $0.044^{\mathrm{a}}$ & $0.042^{a b}$ & $0.038^{b}$ \\
\hline $\mathrm{Na}_{2} \mathrm{O}(\mathrm{ppm})$ & & $0.01^{\mathrm{b}}$ & $0.02^{b}$ & $0.02^{b}$ & $0.04^{\mathrm{a}}$ & $0.01^{b}$ \\
\hline $\mathrm{B}(\mathrm{ppm})$ & & $23.45^{\mathrm{ab}}$ & $10.08^{c}$ & $24.27^{\mathrm{ab}}$ & $18.14^{b}$ & $29.30^{\mathrm{a}}$ \\
\hline $\mathrm{Al}(\mathrm{ppm})$ & & $436.88^{c}$ & $44.20^{\mathrm{d}}$ & $734.00^{b}$ & $47.16^{\mathrm{d}}$ & $1056.24^{\mathrm{a}}$ \\
\hline $\mathrm{Ti}(\mathrm{ppm})$ & & $32.81^{b}$ & $2.98^{\mathrm{c}}$ & $67.74^{\mathrm{a}}$ & $3.79^{c}$ & $67.58^{\mathrm{a}}$ \\
\hline $\mathrm{Cr}(\mathrm{ppm})$ & & $1.75^{\mathrm{a}}$ & $0.58^{\mathrm{a}}$ & $1.89^{\mathrm{a}}$ & $0.32^{\mathrm{b}}$ & $1.65^{\mathrm{a}}$ \\
\hline $\mathrm{Mn}(\mathrm{ppm})$ & & $50.39^{b}$ & $8.86^{\mathrm{d}}$ & $33.69^{c}$ & $5.86^{\mathrm{e}}$ & $92.96^{\mathrm{a}}$ \\
\hline $\mathrm{Fe}(\mathrm{ppm})$ & & $264.56^{\mathrm{c}}$ & $38.21^{\mathrm{d}}$ & $408.90^{\mathrm{b}}$ & $37.56^{\mathrm{d}}$ & $540.20^{\mathrm{a}}$ \\
\hline $\mathrm{Ni}(\mathrm{ppm})$ & & $0.52^{\mathrm{a}}$ & $0.41^{\mathrm{b}}$ & $0.49^{a b}$ & $0.23^{\mathrm{c}}$ & $0.58^{a}$ \\
\hline $\mathrm{Cu}(\mathrm{ppm})$ & & $4.58^{\mathrm{c}}$ & $4.64^{c}$ & $7.71^{\mathrm{a}}$ & $6.04^{\mathrm{b}}$ & $4.79^{c}$ \\
\hline $\mathrm{Zn}(\mathrm{ppm})$ & & $12.53^{\mathrm{c}}$ & $8.37^{d}$ & $20.08^{b}$ & $9.63^{\mathrm{d}}$ & $24.25^{\mathrm{a}}$ \\
\hline As (ppm) & & $0.28^{a}$ & $0.17^{\mathrm{b}}$ & $0.28^{a}$ & $0.07^{\mathrm{c}}$ & $0.28^{a}$ \\
\hline Mo (ppm) & & $0.54^{\mathrm{b}}$ & $1.32^{\mathrm{a}}$ & $0.45^{\mathrm{c}}$ & $0.37^{\mathrm{d}}$ & $0.57^{\mathrm{b}}$ \\
\hline Total & & 832.21 & 122.92 & 1304.03 & 133.86 & 1822.13 \\
\hline
\end{tabular}

${ }^{a-c}$ Means within a row followed by the same letters are not significantly different at $5 \%$ level according to Duncan's Multiple Range Test. 
Furthermore, Bortytis cinerea and Colletotrichum coccodes were suppressed by $92 \%$ and $57 \%$ by boiled water extracts of SL at $5 \%$, respectively, when compared with the control. Many studies have reported suppression rates of crop pathogens in response to treatment with plant extracts (Jang et al., 2016a, 2016b; Abdelgaleil et al., 2019). For example, rice blast was completely suppressed by $3 \%$ boiling extracts in Rheum palmatum roots, Camellia japonica stems, Pittosporum tobira leaves, and Styrax japonica leaves among 20 plant species from 11 families. However, the plant extracts used in this study led to pathogen suppression as well as crop growth promotion. Additional research is required to elucidate the suppression mechanisms of Bortytis cinerea in SL extracts.

The reductions in cucumber powdery mildew in cucumber plants in response to treatment with CC, SL and stem extracts at 1,
3 , and 5\% were all below 19\% (Figure 1). Conversely, the acaricidal activities of CC, SL and SS extracts at 3, 5, and 10\% against two-spotted spider mites were below $28 \%$ (Figure 2). Thus, the selected plant extracts do not seem to exert any direct control on cucumber powdery mildew or two-spotted spider mites.

\section{Responses to plants treated with selected plant extracts to various environmental stresses}

Treatment of cucumber plants with CC, SL and SS extracts did not show any effects on chilling tolerance when compared with control plants (data not shown). However, in another study, freezing tolerance of grapes was improved by an A. nodosum extract formulation, which resulted in reduced osmotic potential of the leaves, a key indicator of osmotic tolerance (Wilson, 2001).

To the best of our knowledge, no studies have established

Table 3. Chemical compositions in selected plant extracts.

\begin{tabular}{|c|c|c|c|c|c|c|c|}
\hline \multirow[t]{2}{*}{ Element } & & \multicolumn{2}{|c|}{ Chinese chive } & \multicolumn{2}{|c|}{ Soybean leaf } & \multicolumn{2}{|c|}{ Soybean stem } \\
\hline & & Water & Ethanol & Water & Ethanol & Water & Ethanol \\
\hline Ex. Cat $(\mathrm{cmol}+/ \mathrm{kg})$ & $\begin{array}{l}\mathrm{K} \\
\mathrm{Ca} \\
\mathrm{Mg}\end{array}$ & $\begin{array}{l}0.07^{\mathrm{c}} \\
0.16^{\mathrm{b}} \\
0.10^{\mathrm{b}}\end{array}$ & $\begin{array}{l}0.542^{\mathrm{a}} \\
0.023^{\mathrm{c}} \\
0.024^{\mathrm{d}}\end{array}$ & $\begin{array}{l}0.02^{\mathrm{d}} \\
0.87^{\mathrm{a}} \\
0.23^{\mathrm{a}}\end{array}$ & $\begin{array}{c}0.105^{\mathrm{b}} \\
0.059^{\mathrm{c}} \\
0.012^{\mathrm{de}}\end{array}$ & $\begin{array}{l}0.01^{d} \\
0.11^{b} \\
0.06^{c}\end{array}$ & $\begin{array}{l}0.090^{\mathrm{b}} \\
0.008^{\mathrm{d}} \\
0.004^{\mathrm{e}}\end{array}$ \\
\hline Av. $\mathrm{P}_{2} \mathrm{O}_{5}(\mathrm{mg} / \mathrm{kg})$ & & $0.07^{\mathrm{a}}$ & $0.009^{c}$ & $0.02^{\mathrm{b}}$ & - & $0.01^{\mathrm{b}}$ & - \\
\hline T-N (\%) & & $0.68^{\mathrm{a}}$ & $0.34^{b}$ & $0.24^{b}$ & $0.035^{c}$ & $0.09 \mathrm{~d}$ & $0.018^{d}$ \\
\hline $\mathrm{Na}_{2} \mathrm{O}$ (ppm) & & $0.09^{\mathrm{a}}$ & $0.003^{b}$ & $0.01^{\mathrm{a}}$ & $0.002^{b}$ & $0.0^{\mathrm{b}}$ & $0.002^{\mathrm{b}}$ \\
\hline $\mathrm{B}(\mathrm{ppm})$ & & $2.78^{b}$ & $0.360^{\mathrm{d}}$ & $6.15^{\mathrm{a}}$ & $0.398^{d}$ & $1.35^{\mathrm{c}}$ & $0.157^{\mathrm{d}}$ \\
\hline $\mathrm{Al}(\mathrm{ppm})$ & & $14.99^{\mathrm{bc}}$ & $21.798^{b}$ & $55.27^{\mathrm{a}}$ & $18.228^{\mathrm{b}}$ & $10.4^{\mathrm{c}}$ & $1.848^{\mathrm{d}}$ \\
\hline $\mathrm{Ti}$ (ppm) & & $1.26^{\mathrm{b}}$ & $0.849^{\mathrm{bc}}$ & $3.09^{\mathrm{a}}$ & $0.992^{\mathrm{bc}}$ & $0.64^{\mathrm{c}}$ & $0.090^{\mathrm{d}}$ \\
\hline $\mathrm{Cr}(\mathrm{ppm})$ & & $0.49^{a}$ & $0.591^{\mathrm{a}}$ & $0.39^{b}$ & $0.144^{c}$ & $0.15^{\mathrm{c}}$ & $0.117^{c}$ \\
\hline $\mathrm{Mn}$ (ppm) & & $7.26^{\mathrm{b}}$ & $1.400^{\text {cd }}$ & $41.96^{\mathrm{a}}$ & $2.978^{\mathrm{c}}$ & $1.76^{\mathrm{cd}}$ & $0.165^{\mathrm{e}}$ \\
\hline $\mathrm{Fe}(\mathrm{ppm})$ & & $19.58^{\mathrm{b}}$ & $10.955^{c}$ & $41.23^{\mathrm{a}}$ & $10.882^{\mathrm{c}}$ & $8.29 c$ & $1.142^{\mathrm{d}}$ \\
\hline $\mathrm{Ni}(\mathrm{ppm})$ & & $0.13^{\mathrm{a}}$ & $0.004^{\mathrm{a}}$ & $0.02^{\mathrm{a}}$ & $0.005^{\mathrm{a}}$ & $0.03^{\mathrm{a}}$ & - \\
\hline $\mathrm{Cu}(\mathrm{ppm})$ & & $1.23^{\mathrm{a}}$ & $0.591^{\mathrm{b}}$ & $0.88^{b}$ & $0.144^{c}$ & $1.2^{\mathrm{a}}$ & $0.117^{c}$ \\
\hline Zn (ppm) & & $10.11^{\mathrm{a}}$ & $0.174^{\mathrm{d}}$ & $7.3^{\mathrm{ab}}$ & $1.058^{c}$ & $1.2^{\mathrm{c}}$ & $3.265^{\mathrm{b}}$ \\
\hline As (ppm) & & $0.58^{\mathrm{a}}$ & $0.333^{b}$ & $0.46^{\mathrm{b}}$ & $0.385^{\mathrm{b}}$ & $0.4^{\mathrm{b}}$ & $0.479^{\mathrm{ab}}$ \\
\hline Mo (ppm) & & $0.70^{\mathrm{a}}$ & - & $0.03^{\mathrm{a}}$ & - & - & $0.041^{\mathrm{a}}$ \\
\hline Total & & 60.28 & 37.99 & 158.17 & 35.42 & 25.70 & 7.54 \\
\hline
\end{tabular}

a-eMeans Means within a row followed by the same letters are not significantly different at 5\% level according to Duncan's Multiple Range Test.

Table 4. Changes in quantum yield, chlorophyll, and carotenoid contents of lettuce plants after treatments of selected plant water extracts. Parameters were measured at 7 days after treatment.

\begin{tabular}{|c|c|c|c|c|c|c|c|}
\hline \multirow[t]{2}{*}{ Extract } & \multirow[t]{2}{*}{ Conc. (\%) } & \multicolumn{4}{|c|}{ Quantum yield } & \multirow{2}{*}{$\begin{array}{c}\text { Total chlorophyll } \\
\text { ( } \mu \mathrm{g} / \mathrm{mg} \text { FW. } \\
7 \mathrm{DAT}\end{array}$} & \multirow{2}{*}{$\begin{array}{c}\text { Total carotenoid } \\
\text { ( } \mu \text { g/mg FW.) } \\
7 \text { DAT }\end{array}$} \\
\hline & & $1 \mathrm{DAT}$ & 3 DAT & 5 DAT & $7 \mathrm{DAT}$ & & \\
\hline Control & & $0.770^{\mathrm{a}}$ & $0.762^{b}$ & $0.742^{\mathrm{a}}$ & $0.759^{\mathrm{abc}}$ & $2.57^{\mathrm{a}}$ & $0.48^{\mathrm{abc}}$ \\
\hline Chinese chive & $\begin{array}{l}1 \\
3 \\
5\end{array}$ & $\begin{array}{l}0.767^{\mathrm{a}} \\
0.762^{\mathrm{a}} \\
0.758^{\mathrm{a}}\end{array}$ & $\begin{array}{l}0.767^{\mathrm{ab}} \\
0.778^{\mathrm{ab}} \\
0.770^{\mathrm{ab}}\end{array}$ & $\begin{array}{l}0.768^{\mathrm{a}} \\
0.772^{\mathrm{a}} \\
0.775^{\mathrm{a}}\end{array}$ & $\begin{array}{c}0.754^{\mathrm{abc}} \\
0.778^{\mathrm{a}} \\
0.765^{\mathrm{abc}} \\
\end{array}$ & $\begin{array}{l}2.54^{\mathrm{a}} \\
2.81^{\mathrm{a}} \\
2.70^{\mathrm{a}}\end{array}$ & $\begin{array}{c}0.53^{\mathrm{abc}} \\
0.56^{\mathrm{ab}} \\
0.58^{\mathrm{a}}\end{array}$ \\
\hline Soybean leaf & $\begin{array}{l}1 \\
3 \\
5\end{array}$ & $\begin{array}{l}0.767^{\mathrm{a}} \\
0.768^{\mathrm{a}} \\
0.766^{\mathrm{a}}\end{array}$ & $\begin{array}{l}0.774^{\mathrm{ab}} \\
0.772^{\mathrm{ab}} \\
0.771^{\mathrm{ab}}\end{array}$ & $\begin{array}{l}0.767^{\mathrm{a}} \\
0.769^{\mathrm{a}} \\
0.774^{\mathrm{a}}\end{array}$ & $\begin{array}{l}0.741^{\mathrm{c}} \\
0.748^{\mathrm{bc}} \\
0.767^{\mathrm{abc}}\end{array}$ & $\begin{array}{l}2.32^{\mathrm{a}} \\
2.16^{\mathrm{a}} \\
2.39^{\mathrm{a}}\end{array}$ & $\begin{array}{l}0.48^{\mathrm{abc}} \\
0.45^{\mathrm{bc}} \\
0.49^{\mathrm{abc}}\end{array}$ \\
\hline Soybean stem & $\begin{array}{l}1 \\
3 \\
5\end{array}$ & $\begin{array}{l}0.767^{\mathrm{a}} \\
0.744^{\mathrm{a}} \\
0.770^{\mathrm{a}}\end{array}$ & $\begin{array}{l}0.772^{\mathrm{ab}} \\
0.780^{\mathrm{a}} \\
0.773^{\mathrm{ab}}\end{array}$ & $\begin{array}{l}0.770^{\mathrm{a}} \\
0.768^{\mathrm{a}} \\
0.774^{\mathrm{a}}\end{array}$ & $\begin{array}{c}0.768^{\mathrm{abc}} \\
0.775^{\mathrm{ab}} \\
0.771^{\mathrm{ab}}\end{array}$ & $\begin{array}{l}2.52^{\mathrm{a}} \\
2.59^{\mathrm{a}} \\
2.33^{\mathrm{a}}\end{array}$ & $\begin{array}{c}0.42^{\mathrm{c}} \\
0.51^{\mathrm{abc}} \\
0.49^{\mathrm{abc}}\end{array}$ \\
\hline
\end{tabular}

FW, fresh weight; DAT, days after treatment. a-c-Means within a column followed by the same letters are not significantly different at 5\% level according to Duncan's Multiple Range Test. 
whether plant extracts, CC, SL and SS and their chemical components could protect plants against salinity stresses. Rice plants did not show any leaf injury in response to plant extracts, except for $\mathrm{CC}$ at 1 and 3\% (Table 6, Figure 3). Injuries to rice plants caused by $50 \mathrm{mM} \mathrm{NaCl}$ were reduced by $20-39 \%, 41-46 \%$, and $40-46 \%$ in response to $\mathrm{CC}, \mathrm{SL}$ or $\mathrm{SS}$ extract treatments at $0.5,1$, and $3 \%$, respectively, when compared with $50 \mathrm{mM} \mathrm{NaCl}$ treatment alone. Shoot fresh weight of rice subjected to $50 \mathrm{mM}$ also increased by $38 \%, 15-52 \%$, and $40-59 \%$ in response to CC, SL or SS extract treatments at $0.5,1$, and $3 \%$, respectively, when compared with 50 $\mathrm{mM} \mathrm{NaCl}$ treatment alone. However, plant height did not vary significantly between the control and $\mathrm{NaCl}$ treatment.

These findings are very important because salinity is one of the most serious abiotic stress factors limiting plant growth, photosynthesis, protein synthesis, and productivity (Mohamed and Gomaa, 2012). Approximately $22 \%$ of the world's agricultural land is saline (FAO, 2017). Similar to this study, Yan (1993) demonstrated that the uptake of $\mathrm{Na}$ ions was reduced in grass treated with sea-

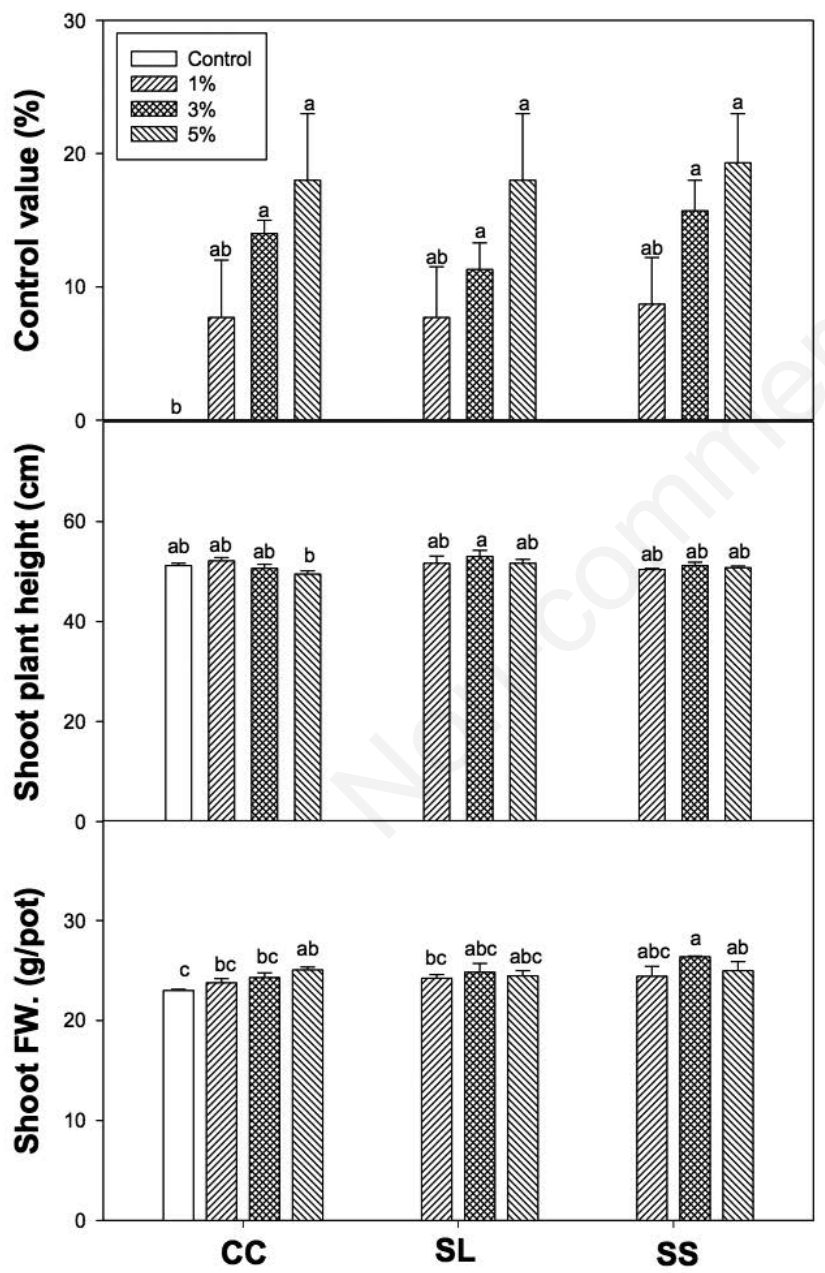

Figure 1. Effect of selected plant water extracts (CC, Chinese chive; SL, soybean leaf; SS, soybean stem) on control of cucumber powdery mildew in cucumber plants in greenhouse. Parameters were recorded at 3 days after treatment. Means within bars followed by the same letters are not significantly different at $5 \%$ level according to Duncan's Multiple Range Test. weed. In addition, seaweed extract treatments have been reported to increase the tolerance of turfgrass to salinity (Nabati et al., 1994; Elansary et al., 2017). Additionally, foliar application of Moringa oleifera leaf extract detoxified the stress generated by $\mathrm{NaCl}$ in bean (Phaseolus vulgaris L.) plants (Howladar, 2014).

Rice injuries under drought conditions were reduced 20-26\% in response to treatment with $\mathrm{CC}, \mathrm{SL}$ and SS extracts at 1, 3, and $5 \%$ when compared with control plants (Table 7, Figure 4). Furthermore, the shoot fresh weight of rice under drought conditions increased by $3.6,2$, and 3.2 times in response to treatment with CC, SL and SS extracts at 5\%, respectively, when compared with control plants. However, plant height under drought conditions were increased $7-20 \%$ in response to treatment with CC, SL and SS extracts at 3 and 5\% when compared with control plants. Plant growth is dependent on the availability of water, and water stress hampers plant performance through disruption of metabolic pathways. The loss of integrity of biological membranes, as a result of oxidative damage, is another negative impact of drought

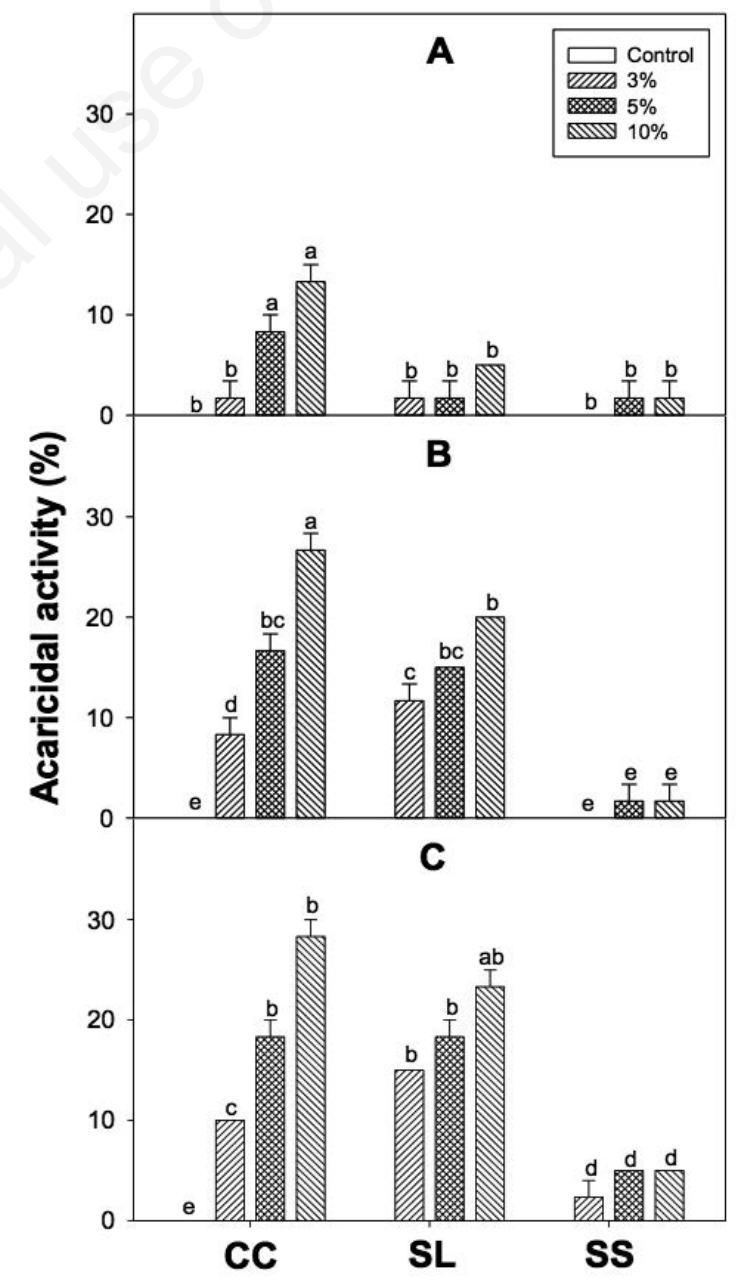

Figure 2. Acaricidal activity of selected plant water extracts (CC, Chinese chive; SL, soybean leaf; SS, soybean stem) against Tetranychus urticae in a laboratory bioassay. A, 1 day after treatment (DAT); B, 3 DAT; C, 5 DAT. Means within bars followed by the same letters are not significantly different at $5 \%$ level according to Duncan's Multiple Range Test. 
Table 5. Effect of leguminous crop extracts at $5 \%$ concentration on suppression activity of five pathogens. Parameter was recorded at 3 days after treatment.

\begin{tabular}{|c|c|c|c|c|c|c|c|}
\hline \multirow{2}{*}{$\begin{array}{l}\text { Plant } \\
\text { Control }\end{array}$} & \multirow[t]{2}{*}{ Plant part } & \multirow[t]{2}{*}{ Extract method } & \multicolumn{5}{|c|}{ Suppression activity (\%) } \\
\hline & & & $\begin{array}{l}\text { PO } \\
0.0 f\end{array}$ & $\begin{array}{l}\text { RS } \\
0.0 \mathrm{j}\end{array}$ & $\begin{array}{c}\text { PC } \\
0.0 \mathrm{e}\end{array}$ & $\begin{array}{c}\mathrm{BC} \\
0.0 \mathrm{~h}\end{array}$ & $\begin{array}{l}\mathrm{CC} \\
0.0 \mathrm{f}\end{array}$ \\
\hline Mung beam & Leaf & $\begin{array}{c}\text { Water } \\
\text { Boiled water } \\
\text { Ethanol } \\
\text { Water } \\
\text { Boiled water } \\
\text { Ethanol }\end{array}$ & $\begin{array}{c}27.3^{\mathrm{c}} \\
17.2^{\mathrm{de}} \\
0.0^{\mathrm{f}} \\
0.0^{\mathrm{f}} \\
0.0^{\mathrm{f}} \\
0.0^{\mathrm{f}}\end{array}$ & $\begin{array}{l}45.9^{\mathrm{bc}} \\
33.0^{\mathrm{d}} \\
12.8^{\mathrm{gh}} \\
21.1^{\mathrm{ef}} \\
17.4^{\mathrm{fg}} \\
3.7^{\mathrm{ij}}\end{array}$ & $\begin{array}{l}36.1^{\mathrm{a}} \\
2.8^{\mathrm{e}} \\
0.0^{\mathrm{e}} \\
2.8^{\mathrm{e}} \\
0.0^{\mathrm{e}} \\
0.0^{\mathrm{e}}\end{array}$ & $\begin{array}{l}25.5^{\mathrm{c}} \\
0.0^{\mathrm{h}} \\
0.0^{\mathrm{h}} \\
0.0^{\mathrm{h}} \\
0.0^{\mathrm{h}} \\
0.0^{\mathrm{h}}\end{array}$ & $\begin{array}{l}27.3^{\mathrm{c}} \\
2.3^{\mathrm{f}} \\
0.0^{\mathrm{f}} \\
0.0^{\mathrm{f}} \\
0.0^{\mathrm{f}} \\
0.0^{\mathrm{f}}\end{array}$ \\
\hline Cowpea & Leaf & $\begin{array}{c}\text { Water } \\
\text { Boiled water } \\
\text { Ethanol } \\
\text { Water } \\
\text { Boiled water } \\
\text { Ethanol }\end{array}$ & $\begin{array}{c}17.2^{\mathrm{de}} \\
0.0^{\mathrm{f}} \\
0.0^{\mathrm{f}} \\
0.0^{\mathrm{f}} \\
55.6^{\mathrm{a}} \\
0.0^{\mathrm{f}}\end{array}$ & $\begin{array}{c}51.4^{\mathrm{b}} \\
20.2^{\text {ef }} \\
8.3^{\text {hi }} \\
43.1^{\mathrm{c}} \\
58.7^{\mathrm{a}} \\
23.1^{\text {ef }}\end{array}$ & $\begin{array}{c}13.9^{\mathrm{bc}} \\
0.0^{\mathrm{e}} \\
0.0^{\mathrm{e}} \\
0.0^{\mathrm{e}} \\
6.2^{\mathrm{de}} \\
3.1^{\mathrm{e}}\end{array}$ & $\begin{array}{c}23.6^{\mathrm{c}} \\
0.0^{\mathrm{h}} \\
0.0^{\mathrm{h}} \\
0.0^{\mathrm{h}} \\
21.2^{\mathrm{d}} \\
0.0^{\mathrm{h}}\end{array}$ & $\begin{array}{c}21.3^{\mathrm{d}} \\
0.0^{\mathrm{f}} \\
4.3^{\mathrm{f}} \\
0.0^{\mathrm{f}} \\
34.0^{\mathrm{b}} \\
0.0^{\mathrm{f}}\end{array}$ \\
\hline Soybean & Stem & $\begin{array}{c}\text { Water } \\
\text { Boiled water } \\
\text { Ethanol } \\
\text { Water } \\
\text { Boiled water } \\
\text { Ethanol }\end{array}$ & $\begin{array}{c}11.1^{\mathrm{e}} \\
33.3^{\mathrm{b}} \\
11.1^{\mathrm{e}} \\
0.0^{\mathrm{f}} \\
0.0^{\mathrm{f}} \\
0.0^{\mathrm{f}}\end{array}$ & $\begin{array}{l}42.3^{\mathrm{c}} \\
31.7^{\mathrm{d}} \\
24.0^{\mathrm{ef}} \\
20.2^{\mathrm{ef}} \\
21.2^{\mathrm{ef}} \\
27.9^{\mathrm{de}}\end{array}$ & $\begin{array}{l}9.4^{\mathrm{cd}} \\
18.8^{\mathrm{b}} \\
4.7^{\mathrm{de}} \\
0.0^{\mathrm{e}} \\
0.0^{\mathrm{e}} \\
0.0^{\mathrm{e}}\end{array}$ & $\begin{array}{c}46.2^{\mathrm{b}} \\
92.3^{\mathrm{a}} \\
17.3^{\mathrm{e}} \\
0.0^{\mathrm{h}} \\
0.0^{\mathrm{h}} \\
11.5^{\mathrm{f}}\end{array}$ & $\begin{array}{c}27.3^{\mathrm{c}} \\
56.8^{\mathrm{a}} \\
22.7^{\mathrm{cd}} \\
0.0^{\mathrm{f}} \\
0.0^{\mathrm{f}} \\
4.5 \mathrm{f}^{\mathrm{f}}\end{array}$ \\
\hline Red bean & Leaf & $\begin{array}{c}\text { Water } \\
\text { Boiled water } \\
\text { Ethanol }\end{array}$ & $\begin{array}{c}33.3^{b} \\
22.2^{d} \\
0.0^{f}\end{array}$ & $\begin{array}{l}49.0^{\mathrm{bc}} \\
44.2^{\mathrm{bc}} \\
27.9^{\mathrm{de}}\end{array}$ & $\begin{array}{c}20.3^{\mathrm{b}} \\
0.0^{\mathrm{e}} \\
0.0^{\mathrm{e}}\end{array}$ & $\begin{array}{l}25.0^{\mathrm{c}} \\
5.8^{\mathrm{g}} \\
0.0^{\mathrm{h}}\end{array}$ & $\begin{array}{c}15.9^{\mathrm{e}} \\
4.5^{\mathrm{f}} \\
0.0^{\mathrm{f}}\end{array}$ \\
\hline
\end{tabular}

PO, Pyricularia oryzae; BC, Bortytis cinerea; RS, Rhizoctonia solani; PC, Phytophthora capsici; CC, Colletotrichum coccodes. a-jMeans within a column followed by the same letters are not significantly different at $5 \%$ level according to Duncan's Multiple Range Test.

Table 6. Effect of selected plant water extracts on leaf injury, plant height, and shoot fresh weight of rice plants after $\mathrm{NaCl}$ treatments.

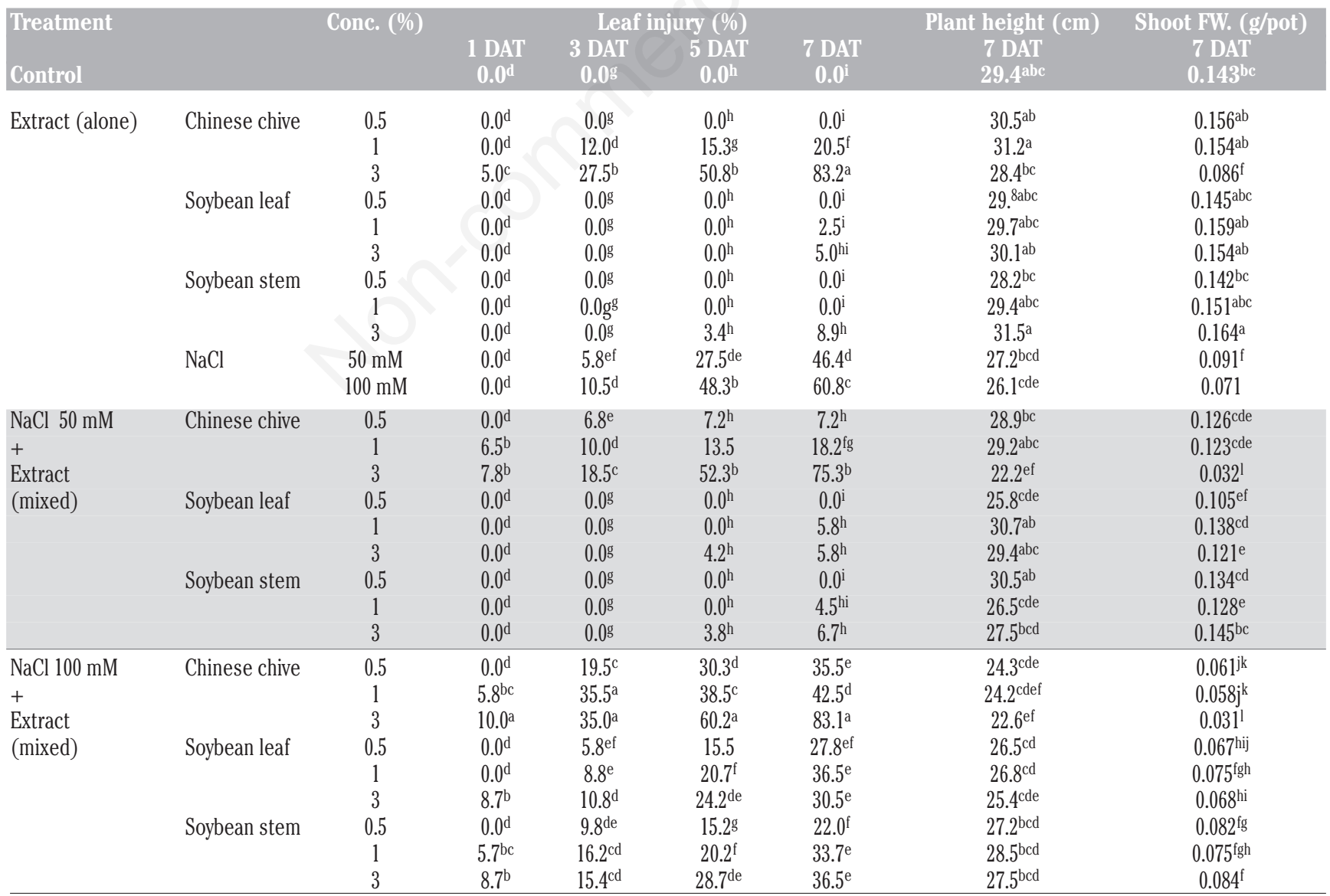

FW, fresh weight; DAT, days after treatment. a-lMeans within a column followed by the same letters are not significantly different at $5 \%$ level according to Duncan's Multiple Range Test. 
stress on plants ( $\mathrm{Li}$ and Van Staden, 1998; Feng et al., 2007). Similar to this study, Moringa oleifera-treated squash plants exposed to deficit irrigation had higher growth and yield characteristics, harvest index, water use efficiency, chlorophyll fluores- cence, and photosynthetic pigments than untreated plants (Abd ElMageed et al., 2017). Thus, plant extracts used in this study that mitigate water stress could contribute substantially to sustainable crop production.
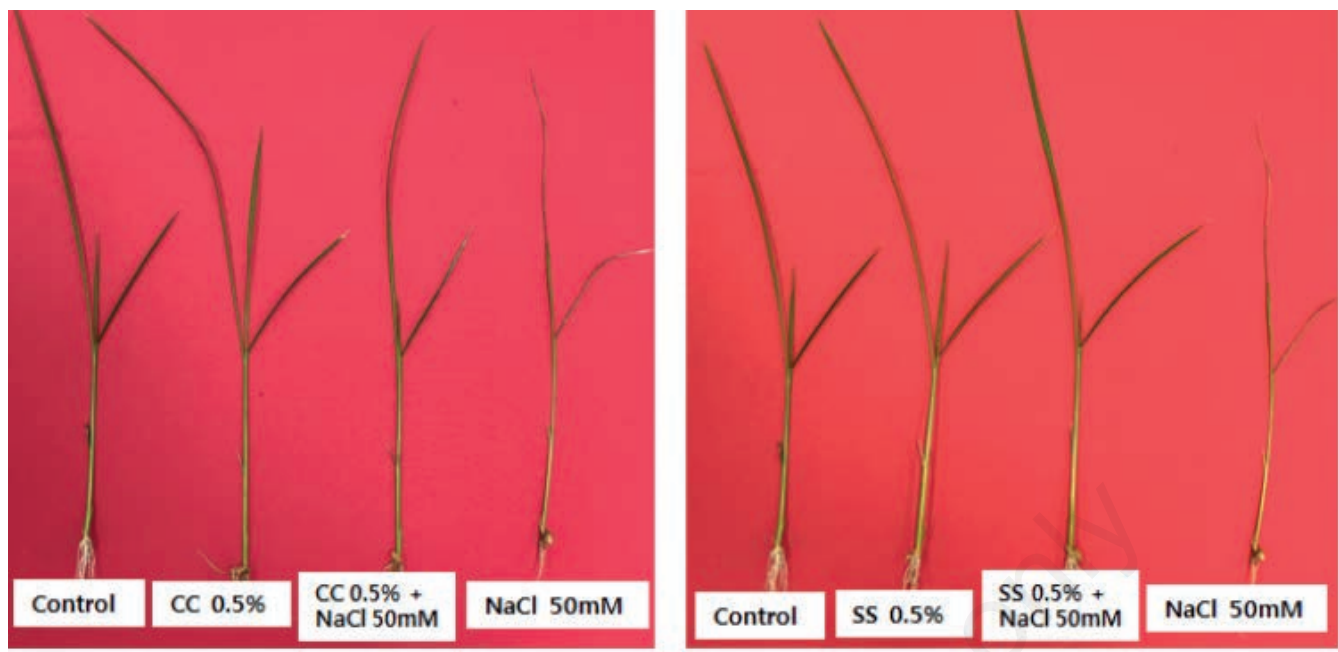

Figure 3. Effect of selected plant water extracts (CC, Chinese chive; SS, soybean stem) and plant extracts $+\mathrm{NaCl} 50 \mathrm{mM}$ on leaf injury of rice. Parameter was recorded at 7 days after treatment.

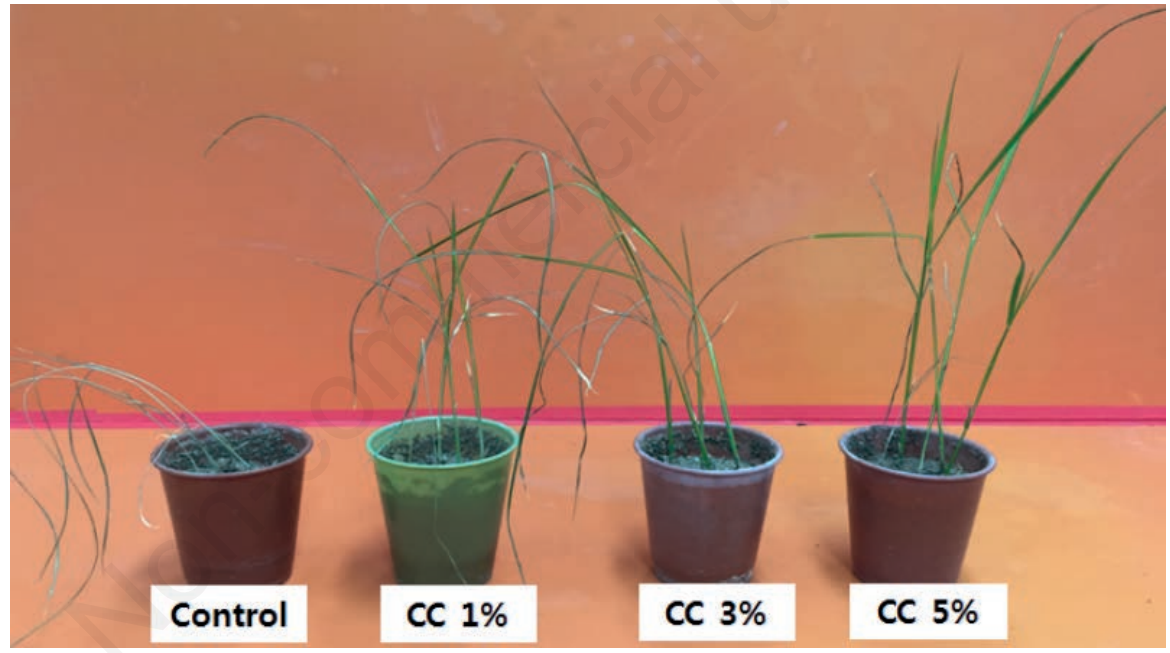

Figure 4. Effect of Chinese chive (CC) water extracts on leaf injury of rice plants under drought conditions. Parameter was recorded at 7 days after treatment.

Table 7. Effect of selected plant water extracts on the leaf injury, recovery rate, plant height, and shoot fresh weight of rice plants under drought conditions.

\begin{tabular}{|c|c|c|c|c|c|c|c|c|c|c|}
\hline \multirow[t]{2}{*}{ Extract } & \multirow[t]{2}{*}{ Conc. (\%) } & \multicolumn{4}{|c|}{ Leaf injury (\%) } & \multicolumn{3}{|c|}{ Recovery rate (\%) } & \multirow{2}{*}{$\begin{array}{c}\text { Plant height }(\mathrm{cm}) \\
7 \text { DAT } \\
27.5^{\mathrm{c}}\end{array}$} & \multirow{2}{*}{$\begin{array}{c}\text { Shoot FW. (g/pot) } \\
7 \mathrm{DAT} \\
0.071^{\mathrm{h}}\end{array}$} \\
\hline & & $\begin{array}{c}1 \mathrm{DAT} \\
0.0^{\mathrm{a}}\end{array}$ & $\begin{array}{c}3 \text { DAT } \\
48.5^{a}\end{array}$ & $\begin{array}{l}5 \text { DAT } \\
67.2^{\mathrm{a}}\end{array}$ & $\begin{array}{l}7 \text { DAT } \\
90.5^{a}\end{array}$ & $\begin{array}{l}1 \mathrm{DAT} \\
78.5^{\mathrm{a}}\end{array}$ & $\begin{array}{l}3 \text { DAT } \\
85.5^{\mathrm{a}}\end{array}$ & $\begin{array}{l}5 \text { DAT } \\
98.5^{\mathrm{a}}\end{array}$ & & \\
\hline \multirow[t]{3}{*}{ Chinese chive } & 1 & $0.0^{\mathrm{a}}$ & $45.2^{\mathrm{b}}$ & $62.3^{\mathrm{ab}}$ & $86.5^{\mathrm{ab}}$ & $65.2^{\mathrm{bc}}$ & $75.5^{\mathrm{b}}$ & $88.5^{\mathrm{bc}}$ & $28.5^{\mathrm{bc}}$ & $0.132^{\mathrm{e}}$ \\
\hline & 3 & $0.0^{\mathrm{a}}$ & $35.2^{\mathrm{e}}$ & $60.0^{c}$ & $77.2^{\mathrm{bc}}$ & $58.5^{\mathrm{c}}$ & $70.3^{\mathrm{bc}}$ & $85.2^{\mathrm{bc}}$ & $32.0^{\mathrm{a}}$ & $0.184^{c}$ \\
\hline & 5 & $0.0^{\mathrm{a}}$ & $26.5^{g}$ & $58.4^{\mathrm{c}}$ & $64.7^{\mathrm{a}}$ & $48.2^{\mathrm{d}}$ & $60.2^{\mathrm{c}}$ & $70.1^{\mathrm{d}}$ & $33.1^{\mathrm{a}}$ & $0.258^{\mathrm{a}}$ \\
\hline \multirow[t]{3}{*}{ Soybean leaf } & 1 & $0.0^{\mathrm{a}}$ & $40.0^{\mathrm{d}}$ & $60.0^{c}$ & $85.0^{\mathrm{ab}}$ & $70.0^{\mathrm{b}}$ & $85.1^{\mathrm{a}}$ & $95.2^{\mathrm{a}}$ & $27.2^{c}$ & $0.082^{\mathrm{g}}$ \\
\hline & 3 & $0.0^{\mathrm{a}}$ & $34.6 \mathrm{e}$ & $52.3^{\mathrm{a}}$ & $75.2^{\mathrm{c}}$ & $68.2^{\mathrm{b}}$ & $77.4^{\mathrm{b}}$ & $90.5^{b}$ & $28.2^{b c}$ & $0.093^{\mathrm{f}}$ \\
\hline & 5 & $0.0^{\mathrm{a}}$ & $30.0^{\mathrm{f}}$ & $50.0^{\mathrm{d}}$ & $72.6^{c}$ & $62.5^{\mathrm{bc}}$ & $67.1^{\mathrm{bc}}$ & $89.8^{b}$ & $30.4 a^{b}$ & $0.141^{\mathrm{d}}$ \\
\hline \multirow[t]{3}{*}{ Soybean stem } & 1 & $0.0^{\mathrm{a}}$ & $43.2^{c}$ & $64.8^{\mathrm{ab}}$ & $85.3^{\mathrm{ab}}$ & $68.9^{\mathrm{b}}$ & $77.5^{\mathrm{b}}$ & $90.5^{b}$ & $28.4^{\mathrm{bc}}$ & $0.082^{\mathrm{g}}$ \\
\hline & 3 & $0.0^{\mathrm{a}}$ & $38.5^{\mathrm{d}}$ & $62.1^{\mathrm{ab}}$ & $80.0^{\mathrm{b}}$ & $59.7^{\mathrm{c}}$ & $68.0^{\mathrm{bc}}$ & $88.5^{\mathrm{bc}}$ & $31.2^{\mathrm{ab}}$ & $0.232^{b}$ \\
\hline & 5 & $0.0^{\mathrm{a}}$ & $27.8^{g}$ & $50.0^{\mathrm{d}}$ & $70.0^{c}$ & $51.5^{\mathrm{cd}}$ & $65.0^{\mathrm{c}}$ & $80.0^{c}$ & $29.5^{\mathrm{b}}$ & $0.234^{\mathrm{b}}$ \\
\hline
\end{tabular}

FW, fresh weight; DAT, days after treatment. ${ }^{\text {a-h}}$ Means within a column followed by the same letters are not significantly different at $5 \%$ level according to Duncan's Multiple Range Test. 


\section{Conclusions}

CC, SL and SS extracts contain macro- and micro-element nutrients which may have multiple functions, including providing $\mathrm{NaCl}$ to crops, improving drought tolerance, reducing fungicidal effects as well as promoting growth. Despite the individual plants having different mineral contents, the growth promotion effects that we observed were similar when the same extraction method was used. This suggests that the extraction method, particularly water extractions, may be responsible for the growth promotion we observed, rather than the plant itself. Lettuce treated with our selected extracts showed no difference in photosynthetic efficiency or chlorophyll and carotenoid contents. The selected plant extracts were effective in controlling certain kinds of fungi such as Bortytis cinerea and Colletotrichum coccodes, but they did little to combat Pyricularia oryzae, Rhizoctonia solani, Phytophthora capsici, cucumber powdery mildew, or two-spotted spider mites. Furthermore, our selected plant extracts reduced rice plant injury caused by salinity and helped rice crops better cope with drought conditions. Due to the fact that the selected plant extracts in this study helped mitigate the effects of drought and salinity, as well as combat fungi and promote growth, we believe that further research into the mechanisms which produced these effects should be conducted and would ultimately contribute to more sustainable crop production methods.

\section{References}

Abdelgaleil SAM, Zoghroban AAM, El-Bakry AM, Kassem SMI, 2019. Insecticidal and antifungal activities of crude extracts and pure compounds from rhizomes of Curcuma longa L. J. Agr. Sci. Tech. 21:1049-61.

Abd El-Rahman SS, Mohamed HI, 2014. Application of benzothiadiazole and Trichoderma harzianum to control faba bean chocolate spot disease and their effect on some physiological and biochemical traits. Acta Physiol. Plant. 36:345-54.

Abd El-Mageed TA, Semida WM, Rady MM, 2017. Moringa leaf extract as biostimulant improves water use efficiency, physiobiochemical attributes of squash plants under deficit irrigation. Agric. Water Manag. 193:46-54.

Arora A, Sairam RK, Srivastava, GC, 2002. Oxidative stress and antioxidative systems in plants. Cur.r Sci. 82:1227-38.

Elansary HO, Yessoufou K, Abdel-Hamid AME, El-Esawi MA, Ali HM, Elshikh MS, 2017. Seaweed extracts enhance Salam turfgrass performance during prolonged irrigation intervals and saline shock. Front. Plant Sci. 8:830.

FAO. 2017. FAO Production Yearbook. FAO, Rome.

Feng H, Li S, Xue L, An L, Wang X, 2007. The interactive effects of enhanced UV-B radiation and soil drought on spring wheat. S. Afr. J. Bot. 73:429-34.

Flowers TJ, Yeo AR, 1995. Breeding for salinity resistance in crop plants: where next? Aust J. Plant Physiol. 22:875-84.

Foidl N, Makkar HPS, Becker K, 2001. The potential of Moringa oleifera for agricultural and industrial uses. In: Fuglie, L.J. (Ed.), The Miracle Tree: The Multiple Attributes of Moringa. Wageningen, The Netherlands, pp 45-76.

Hiscox JD, Israelatam GF, 1979. A method for the extraction of chlorophyll from leaf tissues without marceration. Can. J. Bit. 57:1332-4.

Howladar SM, 2014. A novel Moringa oleifera leaf extract can mitigate the stress effects of salinity and cadmium in bean (Phaseolus vulgaris L.) plants. Ecotoxicol. Environ. Saf. 100:69-75.

Jardin P, 2015. Plant biostimulants: Definition, concept, main categories and regulation. Sci. Hortic. 196:3-14.

Jang SJ, 2017. Control of diseases, insects, and weeds and growth promotion of crops by useful plant extracts (Ph.D. dissertation). South Korea: Sunchon National University. pp 205.

Jang SJ, Kuk YI, 2018. Effects of different fractions of Rheum palmatum root extract and anthraquinone compounds on fungicidal, insecticidal, and herbicidal activities. J. Plant Dis. Protect. 125:451-60.

Jang SJ, Kuk YI, 2019. Growth promotion effects of plant extracts on various leafy vegetable crops. Hortic. Sci. Technol. 37:322-36.

Jang SJ, Yun YB, Kim SS, Shin DY, Hyun KH, Kuk YI, 2016 a. Effect of various plant extracts and organic emulsifiers on control of rice blast (Pyricularia oryzae). J. Food Agric. Environ. 14:104-10.

Jang SJ, Yun YB, Kim SS, Shin DY, Kuk YI, 2016b. Suppression levels of crop pathogens and plants of medicinal plants containing chrysophanol and emodin. J. Food Agric. Environ. 14:48-53.

Khan W, Rayirath UP, Subramanian S, Jithesh MN, Rayorath P, Hodges DM, Critchley AT, Craigie JS, Norrie J, Prithiviraj B, 2009. Seaweed extracts as biostimulants of plant growth and development. J. Plant Growth Regul. 28:386-99.

Latif HH, Mohamed HI, 2016. Exogenous applications of moringa leaf extract effect on retrotransposon, ultrastructural and biochemical contents of common bean plants under environmental stresses. S. Afr. J. Bot. 106:221-31.

Li L, Van Staden J, 1998. Effects of plant growth regulators on drought resistance of two maize cultivars. S. Afr. J. Bot. 64:116-20.

Mittler R. 2002. Oxidative stress, antioxidants and stress tolerance. Trends Plant Sci. 7:405-10.

Mohamed HI, Gomaa EZ, 2012. Effect of plant growth promoting Bacillus subtilis and Pseudomonas fluorescens on growth and pigment composition of radish plants (Raphanus sativus) under $\mathrm{NaCl}$ stress. Photosynthetica. 50:263-72.

Möller M, Smith ML, 1998. The significance of the mineral component of seaweed suspentions on lettuce (Lactuca sativa L.) seedling growth. J. Plant Physiol. 153:658-63.

Moon GS, Ryu BM, Lee MJ, 2003. Components and antioxidant activities of Buchu (Chinese chives) harvested at different times. Korean J. Food Sci. Technol. 35:493-98.

Nabati D, Schmidt R, Parrish D, 1994. Alleviation of salinity stress in Kentucky Bluegrass by plant growth regulators and iron. Crop Sci. 34:198-202.

Nakatani N, 1997. Antioxidants from spices and herbs. P. 64-75. In: Shahidi, F. (Ed.), Natural Antioxidants: Chemistry, Health Effects, and Applications. AOCS Press, Champaign.

Ndhlala AR, Mulaudzi R, Ncube B, Abdelgadir HA, Du Plooy CP, Johannes Van Staden J, 2014. Antioxidant, antimicrobial and phytochemical variations in thirteen Moringa oleifera Lam. cultivars. Molecules. 19:10480-94.

Nouman W, Siddiqui MT, Basra SMA, 2012. Moringa oleifera leaf extract: an innovative priming tool for rangeland grasses. Turk J. Agric For. 36:65-75.

Porter PM, Banwart WL, Hassett JJ, 1985. Phenolic acida and flavonoids in soybean root and leaf extracts. Environ. Exp. Bot. 26:65-73.

Rural Development Administration (RDA). 1998. Guidance Methods for Food Crop Cultivation. pp in 55-56. Suwon: Rural 
Development Administration, Sammi Press.

Rural Development Administration (RDA). 2000. Methods of soil and plant analysis. pp 202 in Suwon: Rural Development Administration, Sammi Press.

Statistical Analysis System [SAS]. 2000. SAS/STAT User's Guide, Version 7, Statistical Analysis System Institute, Electronic Version, Cary, NC.

Stutte CA, Park H, 1973. Effects of nitrogen source on PRE-point and free amino acids in soybean leaves different in phosphorus sensitivity. Kor. J. Soil Sci. Fertil. 6:239-44.

Wang W, Vinocur B, Altman A, 2003a. Plant responses to drought, salinity and extreme temperatures: towards genetic engineering for stress tolerance. Planta. 218:1-14.

Wang Z, Pote J, Huang B, 2003b. Responses of cytokinins, antioxidant enzymes, and lipid peroxidation in shoots of creeping bentgrass to high root-zone temperatures. J. Am. Soc. Hortic. Sci. 128:648-55.

Wilson S, 2001. Frost management in cool climate vineyards. In
University of Tasmania Research Reports- UT 99/1. Australia: Grape and Wine Research \& Development Corporation.

Yan JY, 1993. Influence of plant growth regulators on turfgrass polar lipid composition, tolerance to drought and salinity stresses, and nutrient efficiency (Ph.D. dissertation). Blacksburg: Virginia Polytechnic Institute and State University. pp 150.

Yamego CW, Bengaly MD, Savadoga A, Nikiema PA, Traore SA, 2011. Determination of chemical composition and nutritional values of Moringa oleifera leaves. Pak. J. Nutr. 10:264-8.

Yasmeen A, Basra SMA, Wahid A, Nouman W, Rehman H, 2012. Exploring the potential of moringa (Moringa oleifera) leaf extract (MLE) as seed priming agent in improving wheat performance. Turk. J. Botany. 37:512-20.

Yasmeen A, Basra SMA, Farooq M, Rehman H, Hussain N, Athar HR, 2013. Exogenous application of moringa leaf extract modulates the antioxidant enzyme system to improve wheat performance under saline conditions. Plant Growth Regul. 69:225-33. 